KULTURA

i
POLSKA AKADEMIANAUK

KOMITET SOCJOLOGII

INSTYTUT STUDIÓW POLITYCZNYCH

2008, nr 3

BEATA ARCIMOWICZ

Uniwersytet im. Adama Mickiewicza w Poznaniu

\title{
KOBIETA W RELIGII — JUDAIZM I KARAIMIZM ORAZ ICH WPŁYW NA ROLĘ KOBIETY W SPOŁECZNOŚCI
}

Religia jest niezwykle ważnym czynnikiem $\mathrm{w}$ życiu wielu społeczności ${ }^{1}$, kształtującym ich tożsamościową odrębność jako grupy oraz współtworzącym tożsamość jednostkową poszczególnych ich członków. System wierzeń i praw kształtuje role społeczne, organizację społeczną i wyznacza codzienne funkcjonowanie wyznawców danej religii. Religia może określać wszystkie aspekty ludzkiego życia: od sposobu przechowywania i przygotowywania żywności, przez ustanowienie rytmu dnia i tygodnia, zachowania seksualne, kształt rodziny, aż po ustalanie relacji pomiędzy ludźmi różnej płci i wyznaczanie ról społecznych przez nich pełnionych. Zachowywanie tożsamości narodowej czy etnicznej jest niezwykle ważne zwłaszcza w przypadku grup, które żyjąc w diasporze, są mniejszościami wśród narodów-gospodarzy. Takie grupy są stale wystawione na obce wpływy i mogą być zagrożone asymilacją i utratą odrębności własnej kultury i wiary. Zachowanie tożsamości, tworzonej przede wszystkim przez wyznawaną wiarę, wiąże się z transmisją na kolejne pokolenia tradycji i wzorów ról społecznych wyznaczanych przez daną religię. Grupy, które musiały wyjątkowo dbać o zachowanie odrębności i tożsamości, to niewątpliwie

Adres do korespondencji: Instytut Psychologii, ul. Szamarzewskiego 89, 60-568 Poznań; beata.arcimowicz@amu.edu.pl

1 „Społeczność” rozumiem jako wspólnotę, której istotą jest „przeżywanie i podzielanie tych samych symboli i wartości stanowiących źródło kulturowej tożsamości grupy" (P. Starosta, Społeczność lokalna, w: Encyklopedia socjologii, Oficyna Naukowa, Warszawa 2002, t. 4). Tutaj społeczność jest utożsamiona z grupą mniejszościową (etniczną, narodową, religijną), z której pochodzi i wśród której żyje dana jednostka. Karaimi stanowią mniejszość etniczną, Zydzi stanowią mniejszość narodową (od 14 maja 1948 r., gdy powstało państwo Izrael), poza tym zarówno Karaimi, jak i Żydzi mogą być uznawani za mniejszości religijne w krajach, które zamieszkują. Również w państwie Izrael istnieją różne społeczności, na przykład społeczność haredi (społeczność ultraortodoksyjna), którą można wyróżnić na tle społeczeństwa izraelskiego. Termin „społeczeństwo” uważam za zarezerwowany dla organizacji społecznej wyższego rzędu (np. naród), która może być złożona z poszczególnych społeczności. 
Żydzi i Karaimi, wyznawcy religii monoteistycznych zaliczanych do najstarszych. Łączy je również to, że religia właśnie w najwyższym stopniu stanowi o ich odmienności i odrębności. Przez wiele wieków określenie „Żyd” i „Karaim" oznaczało osobę konkretnego wyznania oraz określonej narodowości (etniczności).

\section{ROLE SPOŁECZNE I ICH PRZEKAZYWANIE}

W wielu kulturach rodzina jest podstawowym systemem organizacji społecznej (Linton 2000, s. 80). W rodzinie zachodzą tak ważne procesy jak socjalizacja i kulturalizacja (Boski 1992, s. 77-78); to z niej wynosimy wzorce zachowań, system wartości, postawy pożądane i akceptowane w społeczności, w której żyjemy, a także podstawową wiedzę o jej symbolach. To w jej obrębie stykamy się po raz pierwszy z osobami pełniącymi określone role społeczne, a przede wszystkim role rodzajowe (Pankowska 2005; Brannon 2002; Linton 2000). Pojęcia roli społecznej i rodzajowej częściowo zachodzą na siebie. Przez rolę społeczną rozumie się różnorodne role, które można pełnić w ogóle, jest to pula ról dostępnych dla członków danej grupy. W pojęciu roli rodzajowej z kolei mieści się wszystko to, czego dane otoczenie społeczne oczekuje, co aprobuje i czego wymaga od kobiety lub mężczyzny. $Z$ jednej strony rolę społeczną można traktować jako kategorię szerszą, rola rodzajowa obejmuje jedynie część ról społecznych. Role społeczne przeznaczone do pełnienia czy dozwolone dla osobnika określonej płci można nazwać rolą rodzajową. Z drugiej strony rolę rodzajową można traktować jako nadrzędną, bo determinującą role społeczne przeznaczone do pełnienia przez jednostkę określonej płci.

Rolę męską lub żeńską można porównać do scenariusza, który należy odegrać. Scenariusz jest specyficzny dla określonego miejsca, czasu i kultury. To on podpowiada, jak należy się zachowywać, jak planować życie, pokazuje miejsce w szeregu pośród innych. Aby właściwie odegrać rolę kobiety lub mężczyzny, należy postępować zgodnie $z$ rozpisanym dla własnej płci scenariuszem (Brannon 2002, s. 183). Gdy jednostka stosuje się do scenariusza, jej zachowanie jest zrozumiałe i akceptowane przez jej otoczenie. Scenariusza dla ról rodzajowych dostarcza niewątpliwie religia, rozumiana jako system wierzeń, tradycji i praw, których należy przestrzegać i które regulują życie wyznawców.

Wielokrotnie używane słowo „rola” powinno zostać w tym miejscu wyjaśnione. Rolę można rozumieć jako konfigurację różnych zachowań służących zaspokajaniu zarówno potrzeb własnych, jak i wymogów społecznych. Jednostka przyswaja te konfiguracje w całości. Gdy wzory zachowań stają się przyzwyczajeniem, przystosowuje się ona do zajmowania pewnej pozycji w swoim otoczeniu i pełnienia roli z tą pozycją związanej. Rola to postawy, wartości i zachowania, które społeczność wyznaczyła osobom mającym w niej określony status społeczny, wynikający na przykład z płci czy pochodzenia (Linton 2000, s. 40,98$)$. 
Aby móc właściwie odgrywać swoją rolę społeczną, jednostka musi ją najpierw poznać i/lub przyswoić. Nie zawsze role pełnione są w sposób $\mathrm{w}$ pełni świadomy, nie zawsze osoba potrafi określić, co konstytuuje jej rolę, gdyż zwykle otoczenie społeczne nie werbalizuje oczekiwań wprost. Ralph Linton (2000, s. 40) tak przedstawia proces uczenia się roli: „Dzięki szkoleniu i naśladownictwu jednostka rozwija nawyki, które sprawiają, że pełni swą rolę społeczną nie tylko skutecznie, ale i w znacznej mierze nieświadomie". Z definicji tej można wyciągnąć dwa ważne wnioski: o sposobie przyswajania roli i naturze tego procesu oraz o nieświadomym wymiarze jej pełnienia.

Uczenie się roli może odbywać się nie wprost, poza językiem, dzięki systemowi subtelnych wpływów. Mechanizmy, które składają się na uczenie się roli, to głównie: warunkowanie instrumentalne, społeczne uczenie się, wykształcanie schematów rodzaju czy też scenariusza rodzaju (zob. Pankowska 2005; Brannon 2002; Aronson, Wilson, Akert 1997). Wymienione mechanizmy przyswajania roli $\mathrm{w}$ większości mogą przebiegać pozajęzykowo, stąd trudności ze zwerbalizowaniem pełnionej roli rodzajowej. Proces uczenia się roli na początku zachodzi w rodzinie, później dołączają się wpływy grupy rówieśniczej. Uczenie to zawsze odbywa się w kontekście społecznym, kulturowym i religijnym. Najważniejszymi osobami uczestniczącymi w procesie uczenia się i kształtowania roli są rodzice, dziadkowie lub opiekunowie dziecka, przekazują oni podstawowe informacje o życiu społecznym i są pierwszymi modelami-reprezentantami płci.

Pełnienie roli w sposób nieświadomy może być konsekwencją prostego procesu psychologicznego, jakim jest wtórna automatyzacja czynności. Zachowania dobrze wyćwiczone wykonuje się przy coraz mniejszym udziale świadomości, a zatem przy zmniejszonej kontroli zachowania i procesów poznawczych, które uległy automatyzacji. Dzięki nabieraniu wprawy i automatyzacji zyskuje się większą skuteczność działania, ale tylko wtedy, gdy warunki działania nie zmieniają się zbytnio (Nęcka, Orzechowski, Szymura 2006, s. 230 -251). W przeciwnym przypadku wyuczone zachowania, wykształcone postawy i system wartości związany z pełnioną rolą nie pozwalają efektywnie działać w nowym otoczeniu (Minkler, Biller 1979).

\section{JUDAIZM I KARAIMIZM}

Judaizm to najstarsza monoteistyczna religia, z której korzenie wywodzą między innymi chrześcijaństwo i islam, a także karaimizm. Żydów nazywa się niekiedy ludźmi Księgi. Świętą księgą judaizmu jest Biblia Hebrajska. Ma ona wiele nazw. Jedna $z$ nich to Tanakh, akronim pochodzący od nazw trzech głównych części Biblii. Za najważniejszą z części uznawana jest Tora, czyli Pięcioksiąg Mojżesza (Robinson 2000, s. 257-309). Judaizm w swych początkach opierał się głównie na Biblii oraz tradycji przekazywanej ustnie. Tradycja ta zaczęła być spisywana przez mędrców żydowskich na początku naszej ery i tak 
powstał Talmud, najpierw jerozolimski (II w. n.e. lub IV w. n.e.), a później babiloński (IV w. n.e. lub $\mathrm{V}$ w. n.e.), ten ostatni został szeroko uznany w świecie żydowskim (w sprawie dat zamknięcia dzieł zob. Pełczyński 2004, s. 7-8; Datner, Kamieńska 1988, s. 5). Choć Biblia jest świętą księgą i z niej wywodzi się judaizm, to dla wyznawców wiary mojżeszowej coraz ważniejszy stawał się Talmud. W VIII w. n.e. Anan Ben Dawid z Basry zaczął sprzeciwiać się jego rosnącej roli i nawoływał do kierowania się tylko Biblią (Kowalski 1929). Osoby, które sympatyzowały z jego stanowiskiem, uważa się za twórców karaimizmu (od hebrajskiego kara - czytać) (Pełczyński 2004, s. 8-13). Pod względem przykazań religijnych i zwyczajów judaizm i karaimizm są do siebie podobne, zwłaszcza w kwestii przykazań i zwyczajów mających umocowanie bezpośrednio w Biblii Hebrajskiej.

Obydwa systemy religijne wykształciły tradycje i zasady współżycia społecznego oparte na świętej księdze i późniejszych ustaleniach myślicieli. Religia wyznaczała kształt codziennego życia, rodziny, struktury społecznej i ról przynależących poszczególnym członkom społeczności. Określała rytm dnia codziennego wyznaczonego czasem modlitw, rytm tygodnia wyznaczało świętowanie szabatu, a rytm roczny święta o rodowodzie biblijnym (np. Pesach) i późniejszym (np. Chanuka). Wyznawcy mieli też obowiązek przykazywania wiary w jedynego Boga i Jego nauki następnym generacjom. W obu grupach, zarówno Żydów, jak i Karaimów, istniał i istnieje duży nacisk na utrzymywanie tradycji. W Biblii wielokrotnie jest zapisane, że sukces i kontynuacja wspólnoty są zależne od znajomości i przestrzegania Bożego prawa oraz przekazywania tych zasad potomnym (Pessah, Qanai, El-Gamil 2003, s. 117). Umożliwia to instytucja rodziny, gdyż - jak pokazały badania - dla formowania żydowskiej tożsamości ponad dwa razy istotniejsza jest rodzina niż edukacja szkolna (Rosen 1979, s. 162).

Zachowywanie tradycji pozwala danej grupie na zachowanie odrębności i tożsamości. Tak jest w przypadku Żydów i Karaimów, którzy przez wieki żyli i nadal żyją w diasporach, stanowiąc mniejszości etniczne lub narodowe. Otoczeni obcą kulturą, chcąc utrzymać swoją odrębność, musieli przeciwdziałać asymilacji. Opierało się to na utrzymywaniu własnej wiary i obrzędów religijnych, na funkcjonowaniu tradycyjnych żydowskich czy karaimskich rodzin oraz na dbaniu o witalność grupy (posiadanie licznego potomstwa). Dbanie o dom oraz dzieci, a przez to o zachowanie tradycji i tożsamości społeczności, w dużym stopniu spoczywało na barkach kobiet.

\section{ROLA I MIEJSCE W SPOŁECZNOŚCI WYZNACZONE KOBIECIE PRZEZ RELIGIĘ}

Płeć to jedna z podstawowych kategorii pozwalających klasyfikować ludzi. Umożliwia ona prosty, bo widoczny „na pierwszy rzut oka” podział. Przynależność do grupy kobiet lub mężczyzn od wieków wyznaczała i nadal wyznacza status jednostki w społeczności. Już w biblijnych przypowieściach zarysowuje 
się widoczna różnica między kobietami a mężczyznami. Wykonują oni różne czynności, zajmują się odmiennymi dziedzinami życia. Aktywność i zainteresowania kobiet dotyczą głównie domu i rodziny, mężczyzna zaś koncentruje swoją działalność i realizuje się poza domem: w pracy i nauce. Najczęściej nie spotyka się kobiet trudniących się „męskimi” zajęciami ani mężczyzn wykonujących zajęcia „kobiece”. Istnieją jednak głosy, że Tanakh, poza małymi wyjątkami, nie ustanawia ról rodzajowych, które mają być pełnione przez kobiety i mężczyzn, ani nie ogranicza kobiet (Pessah, Qanai, El-Gamil 2003, s. 117; Friedman 1987). W Biblii pojawiają się kobiety, które prowadziły negocjacje, zarządzały nieruchomościami, uczestniczyły w procesjach ulicznych razem z mężczyznami, były prorokami (np. Miriam), czyli zajmowały się tym, co zwyczajowo wykonywali mężczyźni (Friedman 1987, s. 479-484). Dopiero w okresie talmudycznym kobiety zostały w zasadzie wyłączone $z$ życia społecznego na rzecz poświęcenia się domowi, mężowi i dzieciom. Jedna $z$ teorii źródeł tego faktu upatruje we wpływach greckich (Friedman 1987). Pomijając dokładną etymologię (biblijną lub pobiblijną) niektórych praw i przepisów religijnych, warto skoncentrować się na miejscu wyznaczanym przez nie kobiecie.

O przeznaczonym im miejscu i roli kobiety nie dowiadywały się bezpośrednio z Biblii czy innych ksiąg, gdyż rzadko miały do nich dostęp. Często nie potrafiły czytać w ogóle lub nie uczono ich języka hebrajskiego - języka użytego do spisania Biblii, Talmudu i respons rabinicznych. Rozstrzygnięcia prawne dotyczące codziennego życia były tworzone przez osoby światłe i biegłe w przepisach religijnych i pismach, czyli przez mężczyzn. W dużo większym stopniu kobiety były świadome swoich obowiązków wobec rodziny (przede wszystkim wobec męża) niż praw im przysługujących. Obowiązków tych i roli w społeczności uczyły się najczęściej od innych kobiet lub mężczyzn (najczęściej mężów) oraz przez biernie uczestnictwo w nabożeństwach, słuchając mężczyzn czytających Torę.

Status kobiety żydowskiej czy karaimskiej w strukturze społecznej nie jest wysoki. Nie powierza się jej stanowisk ważnych dla funkcjonowania grupy, nie ma jej wśród osób decydujących o życiu wspólnoty. Miejsce kobiety jest w domu, a jej życie ogranicza się do bycia żoną i matką. Jej potrzeby mają być związane $z$ gospodarstwem domowym i w nim zaspokajane. Nawet w latach trzydziestych XX wieku o kobiecie karaimskiej pisano: „dba o przytulność i czystość mieszkania, smaczny i zdrowy posiłek dla całej rodziny, o wygodę i odpoczynek w wolnych chwilach dla męża-karmiciela, o zdrowie i wychowanie dzieci. Miłość macierzyńska i poświęcenie się dzieciom kobiety karaimskiej są znane" (Łopatto 1936, s. 74-75). Można jednak zaobserwować swoisty dualizm podejścia do roli pełnionej przez kobietę żydowską czy karaimską w społeczności. $Z$ jednej strony pomijana jest $\mathrm{w}$ rytuałach, modlitwie, pełnionych w społeczności funkcjach (religijnych i formalnych) i w edukacji. Kobiety były trzymane $z$ dala od nauk religijnych i rytuałów w synagogach, nie brały czynnego udziału w czytaniach, nie przewodziły modlitwom, miały osobne miejsce 
w synagodze - na balkonie, z którego mogły oglądać uroczystości nie rozpraszając swoim widokiem i swoim głosem modlących się mężczyzn (Siegel 1997; o kobietach i modlitwie zob. Hauptman 1993). Kobiety żydowskiej na przykład nie należało uczyć Tory, jeden z rabinów w swoim testamencie napisał: „Nakazuję wam, abyście nakazali swym synom, a oni swoim synom, że powinni być ostrożni i nie uczyć swoich córek Tory" (za: Siegel 1997, s. 1). Z drugiej strony kobieta jest obarczona odpowiedzialnością za utrzymywanie tradycji, dalsze trwanie grupy i zachowanie jej tożsamości religijnej i kulturowej. Kobieta zarówno u Karaimów, jak i u Żydów jest podstawą rodziny — dba o jej spójność, o to, by jej członkom dobrze się żyło razem. A rodzina jest najważniejszym środowiskiem, umożliwia transmisję treści religijnych i kulturowych danej grupy i przyczynia się do ciągłości tożsamości i odrębności grupowej (Rosen 1979, s. 160).

Wśród Żydów bardzo ważne jest pochodzenie matki. W judaizmie panuje bowiem matrylineat, to żydostwo matki determinuje tożsamość narodową i religijną dziecka (Sorek 2002). Kobiety karaimskie są w nieco innej sytuacji. Karaimem trzeba się urodzić (Morelowski 1934; o endogamii u Karaimów zob. Czekanowski 1947), dziedziczenie tożsamości odbywa się przez oboje rodziców (Karaimem się jest gdy matka i ojciec są Karaimami) lub tylko po ojcu (Tsoffar 2006). Nadal jednak na kobietach karaimskich spoczywa odpowiedzialność za przekazywanie prawa, tradycji dotyczących menstruacji, narodzin, świąt, życia domowego i doświadczenia ustnie przekazywanej Tory (Tsoffar 2006, s. 5).

\section{PRZEPISY RELIGIJNE I TRADYCJE}

Przedstawiono tu tezę o religii jako czynniku określającym rolę, którą kobieta żydowska czy karaimska pełni w swojej społeczności, oczekiwania i przekonania dotyczące jej pozycji, obowiązków i praw. Aby opisać miejsce kobiety w społeczności, wskazać jej status, należy przejść od rozważań teoretycznych do przykładów zaczerpniętych z obu religii. Przykłady będą opierać się na prawach religijnych wywodzonych jeszcze $z$ Biblii, które dla osób religijnych (w szczególności ortodoksyjnych) są najwyższymi nakazami, a także z późniejszych ustaleń mędrców i rabinów, które ukształtowały się przez wieki trwania religii (halacha) ${ }^{2}$.

\section{Narodziny}

U Żydów i u Karaimów uroczystości związane z narodzinami dziewczynek i chłopców znacznie się od siebie różnią. Narodziny chłopca w obu religiach są powodem do dumy i radości rodziców oraz rodziny. Chłopcom w ósmym dniu

2 Halacha, z hebrajskiego „iść” lub też „ścieżka”, „droga”, jest uznawana za prawo żydowskie, dotyczy kultywowania wiary i zwyczajów codziennych (np. przepisy żywieniowe), reguluje życie religijnych Żydów. 
życia wyprawia się niezmiernie ważną dla całej społeczności uroczystość obrzezanie. Obrzezanie dla każdego Żyda czy Karaima jest symbolem przymierza zawartego przez Boga z Izraelem (Robinson 2000, s. 145-150). O wielkim znaczeniu tego rytuału może świadczyć to, że jest praktykowany nawet w zeświecczonych kręgach. $Z$ mężczyznami Bóg bezpośrednio zawiera przymierze przez rytuał obrzezania. $Z$ kobietami jest ono zawierane niejako pośrednio: najpierw dziewczynka jest związana z Bogiem przez osobę ojca, a później przez osobę męża (Kulp 2007). W przypadku narodzin dziewczynki rodzice wyprawiają skromne przyjęcie dla najbliższej rodziny z drobnym poczęstunkiem. Po narodzinach chłopca organizowane są uroczystości w synagodze, gdzie cała społeczność cieszy się z nowego członka wspólnoty, a w domu rodzinnym dziecka spotyka się bliższa i dalsza rodzina.

Po urodzeniu dziecka kobieta żydowska, a także karaimska, na pewien czas staje się nieczysta - niddah. Uderzający jest fakt dwa razy dłuższego okresu bycia nieczystą $\mathrm{w}$ przypadku urodzenia dziecka płci żeńskiej (80 dni i 40 dni w przypadku urodzenia chłopca; Tsoffar 2006, s. 119-120; Robinson 2000, s. 138-142). W literaturze przedmiotu zajmującej się zwyczajami związanymi z narodzinami i towarzyszącymi im obrzędami kwestia ta nie jest wyjaśniana.

\section{Bar micwa}

Bar micwa (bar mitzvah) jest ceremonią przejścia w dorosłość, oznacza stanie się synem przykazań (bar — syn, mitzvah — przykazanie) (Robinson 2000, s. 157). Od tej pory chłopiec staje się pełnoprawnym członkiem społeczności, jest odpowiedzialny za swoje czyny i swoje grzechy. Ciążą na nim takie obowiązki, jakie są nałożone na innych dorosłych mężczyzn, posiada też ich przywileje. Uroczystości związane z bar micwą są radością nie tylko dla młodzieńca, jego rodziny i najbliższych. Jest to powód do świętowania dla całej wspólnoty synagogalnej (De Vries 2004). W jej poczet wchodzi bowiem kolejny członek mogący uczestniczyć w modlitwach, czytać Torę, tworzyć minjan (grupa co najmniej dziesięciu mężczyzn wymagana do prowadzenia niektórych modlitw). Uroczystość ta jest powodem do dumy dla rodziny chłopca oraz dla niego samego. Stosunkowo niedawno zaczęto urządzać bat micwę (bat córka), czyli odpowiednik bar micwy dla dziewczynek. Bat micwa jest obchodzona od XIX wieku lub według innych źródeł od 1922 r. (zob. Kameraz-Kos 2002, s. 103-106; Robinson 2000, s. 157-159). Uroczystość ta najczęściej jest skromniejsza niż jej męski pierwowzór, wyprawiana zbiorczo dla grup dziewczynek. Nie uprawnia tak jak bar micwa do pełnego uczestniczenia w życiu religijnym społeczności, zwłaszcza społeczności tradycyjnej, ortodoksyjnej.

\section{Prawo niddah}

Prawo niddah, czyli prawo związane z czystością i nieczystością odnosi się do fizjologii kobiecego ciała. Kobieta niddah to kobieta, która miesiączkuje lub 
też urodziła dziecko (lub $z$ innych przyczyn krwawi z dróg rodnych). Niddah oznacza menstruację, upław menstruacyjny, skalanie. Prawo to pochodzi z Biblii, jest zapisane w Księdze Kapłańskiej 12, 2 (Klein 1992). Na kobietę, która jest niddah nałożonych jest bardzo wiele ograniczeń: zakaz współżycia, przebywania $\mathrm{w}$ tym samym łożu $\mathrm{z}$ mężem czy kimkolwiek innym, a po zakończeniu okresu kobieta jest zobowiązana do obmycia się w rytualnej łaźni - mykwie. U Karaimów kobiety niddah nie są dopuszczane do domów modlitwy, nie mogą przebywać w kuchni ani szykować posiłków, najczęściej pozostają w domu, aby unikać kontaktu z innymi ludźmi, nie siadają podczas posiłku do wspólnego stołu z innymi, nawet najbliższą rodziną (Tsoffar 2006; Klein 1992; Robinson 2000). Kobiety karaimskie $z$ wielką uwagą wyliczają, na jakie dni wypadnie im menstruacja. Według swojego cyklu planują uroczystości, takie jak chociażby bar micwę syna, ponieważ gdyby w tym czasie miesiączkowały, nie mogłyby wziąć udziału w tym ważnym wydarzeniu i musiałyby pozostać poza domem modlitwy. Jednak istnieją też święta, których daty są stałe. Ruth Tsoffar przywołuje w swojej książce słowa Karaimki żyjącej w Stanach Zjednoczonych, która $z$ powodu bycia niddah podczas świąt znalazła się sama przy osobnym stole, podczas gdy cała jej rodzina zasiadła do wspólnego posiłku. Ta młoda kobieta, żona i matka wspomina to wydarzenie w następujący sposób:

„To niezręczne, kiedy tak siedzisz sama. Naprawdę. To tak jakby... czujesz się jak pies, naprawdę, czujesz się jak pies. Ale co możesz zrobić? Robisz to z szacunku do starszej osoby, i wiesz, i zdajesz sobie sprawę, że ona [teściowa] tak żyła całe życie i teraz ma 77, 78 lat i nie zamierzam teraz zmieniać jej życia tylko dlatego, że są święta. Niedorzeczne! I czuję, że to jest dobre dla małych dzieci, one wtedy szanują... znają tradycję" (Tsoffar 2006, s. 142).

Powyższa wypowiedź pokazuje, jak traktowana jest kobieta ze względu na fizjologię swojego ciała, nad którą nie ma kontroli i która jest nierozerwalnie związana $z$ jej kobiecością. Ogranicza się też w ten sposób prawo kobiety do intymności, gdyż jej otoczenie wie, kiedy miesiączkuje. Młoda dziewczyna, która dojrzewając musi uporać się z wieloma zmianami w swoim ciele, ponadto zostaje czasowo wykluczona społecznie. Takie traktowanie naturalnego i nierozerwalnego $z$ byciem kobietą procesu może wpływać na postrzeganie siebie i swojej kobiecości. W podejściu do fizjologii kobiecego ciała daje się zauważyć ambiwalencja: $z$ jednej strony menstruacja jest okresem nieczystości i odsunięcia kobiety od męża, rodziny, domu modlitwy, a z drugiej strony związana $z$ menstruacją płodność kobiety jest niezwykle ważna i ceniona przez otoczenie społeczne.

\section{Płodność i posiadanie dzieci}

Kobieta powinna być płodna i rodzić dzieci, gdyż jedną z jej podstawowych ról jest bycie matką. Postacie kobiece pojawiające się w literaturze żydowskiej czy karaimskiej najczęściej są przedstawiane w roli matki (Tsoffar 2006; Baskin 2004). Płodność kobiety jest niezwykle ważna, a konsekwencje niepłodno- 
ści są różne dla kobiety i mężczyzny. Gdy małżonkowie, pomimo konsumpcji związku, przez dziesięć lat nie doczekają się potomstwa, jest to dla mężczyzny podstawa do wzięcia rozwodu, legalnym wówczas (zgodnie z literą prawa religijnego) staje się pojęcie kolejnej żony. Takie ustalenia istnieją zarówno w judaizmie, jak i w karaimizmie (Tsoffar 2006; Baskin 2004; Klein 1992). Niemożność spłodzenia potomka jest przypisywana kobiecie, a nie mężczyźnie. Nieposiadanie potomstwa stawia kobietę na gorszej pozycji, nie jest ona bowiem w stanie wypełnić roli matki, a rozwiedzionej z powodu niepłodności kobiecie niełatwo o kolejne zamążpójście. Brak męża z kolei uniemożliwia pełne realizowanie się $\mathrm{w}$ roli kobiety. W Talmudzie jest zapisane: „Lepiej jest żyć $\mathrm{w}$ zmartwieniu, to znaczy ze złym mężem, niż pozostawać $\mathrm{w}$ wdowieństwie” oraz „Bardziej niż mężczyzna chce się ożenić, kobieta pragnie wyjść za mąż" (Baskin 2004, s. 91).

Wśród Karaimów egipskich rodzenie dziecka wyrażano słowem oznaczającym przynoszenie, co sugerowało, że kobieta rodząca dziecko przynosi dar: dla teściowej, męża i całej społeczności. Dzieci były dla tej grupy nadzieją na ciągłość religii, kultury i tożsamości. W wywiadach przeprowadzonych przez Ruth Tsoffar kobiety karaimskie mówiły o swoich ciałach, że są zaangażowane w ciągłą reprodukcję, walkę i zaszczepianie kultury (Tsoffar 2006, s. 61-62).

\section{IDEALNA ŻONA}

Żona dla Żydów i Karaimów to bardzo ważna osoba. Ona utrzymuje ognisko domowe, rodzi dzieci, dba o nie i o męża, któremu umożliwia życie bez codziennych trosk o rodzinę, tak by mógł poświęcić się nauce i studiowaniu (chodzi o studia religijne). Jednym z najlepiej znanych przykładów dobrej żony oraz wzorem do naśladowania jest żona Rabiego Akiwy ${ }^{3}$, który był jednym $z$ najbardziej szanowanych rabinów i mędrców żydowskich, a edukację religijną umożliwiło mu poświęcenie żony. Mimo wielkiego osobistego cierpienia wysłała ona męża na naukę, co oznaczało jego 24-letnią nieobecność w domu. Uczyniła to dla niego, aby mógł się rozwijać oraz dla dobra wiary (Baskin 2004, s. 93-94).

Mężczyznom zalecano bardzo ostrożne wybieranie żony, najlepiej o niższym statusie, co miało zapewnić jej wdzięczność i uległość (Baskin 2004, s. 93). Cechy cenione przy wyborze żony to między innymi uroda, cnotliwość, sprawiedliwość, bogobojność (Jacobs 2003). Dobra żona to skarb, zła - przekleństwo. Opowieści o dobrych i złych żonach, przekazywane ustnie lub pisemnie, miały pełnić funkcje dydaktyczne. $Z$ jednej strony mężczyznom pokazywały, jak należy postępować wobec kobiet, czego od nich oczekiwać oraz

3 Rabi Akiwa jest współtwórcą Miszny, według tradycji uważa się, że jako jeden z czterech uczonych odbył mistyczną podróż do raju (http://www.schorr.edu.pl/new/index.php3?dzial=3\& id_tematb $=228[6.08 .2008])$. 
gdzie stawiać im granice wolności. Z drugiej strony kobietom pokazywały potencjalne konsekwencje niesubordynacji czy nieprzestrzegania ustanowionego wobec nich prawa. Złe i nieposłuszne żony czekał bowiem rozwód (Baskin 2004). Jednocześnie trudno jest znaleźć w literaturze żydowskiej, karaimskiej czy w Talmudzie opowieści o złych mężach i o tym, co kobiety powinny w takich przypadkach robić.

Oto dotyczące kobiet wypowiedzi rabinów, które pozwalają uświadomić sobie, jaka według uczonych żydowskich mężczyzn miała być idealna żona:

Rabi Hija: „Żona powinna być wzięta głównie ze względu na swoją urodę i głównie ze względu dzieci”; ,Jest dla nas wystarczającym, że wychowują nasze dzieci i wybawiają nas od grzechu (tj. noszą dzieci i zapewniają ujście potrzebom seksualnym)" (za: Baskin 2004, s. 92-93);

Rabi Jerba z Tunezji: „Kobieta nie powinna stawiać wymagań, których jej mąż nie może spełnić”; , nigdy nie powinna być zła na męża ani nie powinna odpowiadać, gdy on w złości krzyczy na nią; w takim czasie powinna kontynuować swoją pracę w milczeniu" (za: Stahl 1985, s. 360);

Rabi Hajm z Iraku: „Mądra kobieta powinna robić prace domowe, gdy jej męża nie ma. Kiedy on wraca $z$ bazaru powinna być gotowa przyjąć go, czysta i w swym najlepszym odzieniu jak panna młoda $\mathrm{w}$ dniu ślubu. W ten sposób jej mąż [...] będzie ją zawsze kochał" (za: Stahl 1985, s. 362).

Według tradycyjnych reguł idealna żona nie miała być partnerką życiową dla swojego męża, nie miała być towarzyszem do rozmów, dyskusji. Miała odgrywać rolę drugorzędną, jednak rola ta była niezwykle ważna dla funkcjonowania podstawowego i zarazem najważniejszego elementu społeczności — rodziny.

Zarysowane tu w niewielkim wycinku przepisy religijne i zwyczaje obowiązujące w judaizmie i karaimizmie mogą dać pewien obraz społeczności religijnej i roli wyznaczonej w niej kobiecie. W społeczności takiej podejście do kobiet jest dualistyczne. $Z$ jednej strony jej status społeczny jest niższy niż mężczyzny, a $z$ drugiej pełnioną przez nią rolę uznaje się za niezwykle ważną dla zachowania spójności i tożsamości grupowej. Kobieta ma być głównie matką i żoną, nie przykłada się dużej wagi do jej kształcenia (czy to religijnego czy świeckiego) (o seksizmie w judaizmie zob. Gold 1997). Jednocześnie składa się na jej ręce bardzo ważną i odpowiedzialną rolę: tworzenia odpowiednich warunków do utrzymywania i przekazywania tradycji, a tym samym zapewnienia przetrwania religii i kultury. Patrząc z perspektywy XXI wieku na historię Karaimów, a tym bardziej Żydów, można stwierdzić, że kobiety skutecznie pełniły tę trudną rolę. Żydzi i Karaimi zachowali swoją tożsamość, która przetrwała wieki.

Ważne jest jednak, aby nie postrzegać negatywnie i jednowymiarowo wizji kobiety i stosunku do niej w społecznościach religijnych. Mędrcy i rabini do- 
ceniali rolę kobiety jako matki i żony, która dba o dom i rodzinę, umożliwia naukę i poświęcenie się studiom religijnym (Baskin 2004). Istnieją i istniały kobiety pełniące role społeczne wykraczające poza role wyznaczane przez płeć i przepisy religijne. Gdyby nie takie kobiety, nie byłoby tak znaczących w ostatnich latach zmian w kręgach judaizmu reformowanego czy konserwatywnego. Różnice w traktowaniu kobiet i w prawach im przysługujących zależały od tego, gdzie dana społeczność żyła. W Stanach Zjednoczonych — kraju wolności obywatelskich i równouprawnienia, gdzie feminizm jest znaczącym ruchem społecznym - zaczęto wprowadzać zmiany w tradycji religijnej dotyczącej kobiet. Tu rozpowszechnił się zwyczaj urządzania bat mitzvah, kobiety zaczęły uczestniczyć w większym stopniu w życiu religijnym wspólnoty, kształcić się w zakresie Biblii i Talmudu oraz pełnić funkcje rabinów (Siegel 1997). Na Bliskim i Dalekim Wschodzie — w krajach w większości muzułmańskich, jak Jemen, gdzie pozycja kobiet $\mathrm{w}$ społeczeństwie jest bardzo niska — prawa i przywileje kobiet żydowskich czy karaimskich nie były przestrzegane (o sytuacji kobiet żydowskich w Jemenie zob. Dahbany-Miraglia 1999).

Rola przypisana kobiecie w społeczności karaimskiej i żydowskiej uległa znacznym przemianom, zwłaszcza w ostatnich dziesięcioleciach. Kobiety przestają określać siebie tylko i wyłącznie jako matki i żony. Zaczynają się realizować w innych rolach, przede wszystkim zawodowych. Najczęściej jednak są one dodatkiem do podstawowych ról matki i żony, z których kobiety rzadko rezygnują (Pankowska 2005). Bycie matką i żoną od wieków było kwintesencją kobiecego życia. Przepisy i tradycje religijne skutecznie „przywiązały” kobiety do tych ról, które na długi czas wyznaczyły ich miejsce w społeczności. Nawet teraz u kobiet nazywających się nowoczesnymi porzucenie lub ograniczenie pełnienia tych ról powoduje wyrzuty sumienia, konflikt między rolą matki i żony a rolą zawodową. Oczekiwania nałożone na kobiety przez tysiąclecia obowiązywania zasad tradycji i religii nadal oddziałują, czasem podświadomie. Golda Meir, premier Izraela w latach 1969-1974, powiedziała: „wewnętrzna walka i rozpacz matki, która chodzi do pracy, nie ma porównania z żadnym ludzkim doświadczeniem" i rozróżniła kobiety, które pracują dlatego, że są do tego zmuszone, oraz takie, które chcą czegoś więcej od życia, dla takich kobiet „nie ma spoczynku” (za: Rosen 1979, s. 168).

Od czasu, gdy Golda Meir wypowiadała te słowa, minęło wiele lat i też wiele się zmieniło. Pomimo modyfikacji, które zachodzą $\mathrm{w}$ postrzeganiu roli kobiety we współczesnym świecie, nadal w judaizmie i karaimizmie rola ta jest rozumiana w sposób tradycyjny, zwłaszcza w nurcie ortodoksyjnym. Dlaczego warto zajmować się tradycjami i przepisami religijnymi, które nie są restrykcyjnie przestrzegane $\mathrm{w}$ obecnych czasach? Ponieważ trudno jest zrozumieć dzisiejszą rolę kobiety bez znajomości jej genezy i czynników ją kształtujących. Tradycyjnie przeznaczona kobiecie rola matki i żony jest głęboko zakorzeniona w świadomości całych społeczności. Chcą tego czy nie, kobiety nadal są postrzegane przez otoczenie przez pryzmat tej roli, a co najważniejsze często 
same siebie tak postrzegają. Pełnienie, lub nie, roli zgodnie ze scenariuszem może wpływać na zadowolenie $z$ siebie kobiety i jej poczucie spełnienia $\mathrm{w}$ życiu, a to bardzo istotna sprawa.

\section{BIBLIOGRAFIA}

Aronson Elliot, Wilson Timothy D., Akert Robin M., 1997, Psychologia spoteczna. Serce $i$ umyst, tłum. Anna Bezwińska i in., Zysk i S-ka, Poznań.

Baskin Judith R., 2004, Bolsters to Their Husbands: Women as Wives in Rabbinic Literature, „European Judaism”, t. 37, nr 2.

Boski Paweł, 1992, O byciu Polakiem w ojczyźnie i o zmianach tożsamości kulturowo-narodowej na obczyźnie, w: Paweł Boski, Maria Jarymowicz, Hanna Malewska-Peyre (red.), Tożsamość a odmienność kulturowa, Instytut Psychologii PAN, Warszawa.

Brannon Linda, 2002, Psychologia rodzaju, tłum. Magdalena Kacmajor, Gdańskie Wydawnictwo Psychologiczne, Gdańsk.

Czekanowski Jan, 1947, Z zagadnień antropologii Karaimów, „Myśl Karaimska”, t. 2.

Dahbany-Miraglia Dina, 1999, Getting Away with Murder: The Application of Marriage Laws in Jewish Yemen, „Women in Judaism: A Multidisciplinary Journal”, t. 2, nr 1.

Datner Szymon, Kamieńska Anna, 1988, Z madrości Talmudu, Państwowy Instytut Wydawniczy, Warszawa.

De Vries Simon P., 2004 [1968], Obrzędy i symbole Żydów, tłum. Andrzej Borawski, Wydawnictwo WAM, Kraków.

Friedman Theodore, 1987, The Shifting Role of Women, From the Bible to Talmud, „Judaism”, t. $36, \mathrm{nr} 4$.

Gold Nora, 1997, Canadian Jewish Women and Their Experiences of Antisemitism and Sexism, „Women in Judaism: A Multidisciplinary Journal”, t. 1, nr 1.

Hauptman Judith, 1993, Women and Prayer: An Attempt to Dispel Some Fallacies, „Judaism”, t. 42 , s. $94-103$.

Jacobs Jill, 2003, „The Defense Has Become the Prosecution:” Ezrat HaNashim, a Thirteenth-century Response to Misogyny, „Women in Judaism: A Multidisciplinary Journal”, t. 3, nr 2.

Kameraz-Kos Ninel, 2002, Święta i obyczaje żydowskie, Cyklady, Warszawa.

Klein Isaac, 1992, A Guide to Jewish Religious Practice, The Jewish Theological Seminary of America, KTAV Publishing House Inc., New York.

Kowalski Tadeusz, 1929, Turecka monografia o Karaimach krymskich, „Myśl Karaimska”, t. 2, s. 1-8.

Kulp Joshua, 2007, Why Aren't Jewish Women Circumcised? Gender and Convenant in Judaism, „Shofar: An Interdisciplinary Journal of Jewish Studies”, t. 25, nr 2.

Linton Ralph, 2000 [1945], Kulturowe podstawy osobowości, tłum. Aleksandra Jasińska-Kania, Wydawnictwo Naukowe PWN, Warszawa.

Łopatto Konstanty, 1936, Krótki zarys higjeny Karaimów w Polsce, „Myśl Karaimska”, t. 2.

Minkler Meredith, Biller Robert P., 1979, Role Shock: A Tool for Conceptualizing Stress Accompanying Disruptive Role Transitions, „Human Relations”, t. 32, nr 2.

Morelowski Marjan, 1934, Tkaniny ludowe karaimskie a sprawa pochodzenia Karaimów krymskich $i$ polskich, „Myśl Karaimska”, t. 10.

Nęcka Edward, Orzechowski Jarosław, Szymura Błażej, 2006, Psychologia poznawcza, Wydawnictwo Naukowe PWN, Warszawa. 
Pankowska Dorota, 2005, Wychowanie a role ptciowe, Gdańskie Wydawnictwo Psychologiczne, Gdańsk.

Pełczyński Grzegorz, 2004, Karaimi polscy, Poznańskie Towarzystwo Przyjaciół Nauk, Poznań.

Pessah Joe, Qanai Avraham, El-Gamil Yosef, 2003, An Introduction to Karaite Judaism: History, Theology, Practice, and Culture, al-Qirqisani Center for the Promotion of Karaite Studies, New York.

Robinson George, 2000, Essential Judaism: A Complete Guide to Beliefs, Customs and Rituals, Pocket Books, New York.

Rosen Gladys, 1979, The Impact of the Women's Movement on the Jewish Family, "Judaism”, t. 28 , nr 2, s. $160-168$.

Siegel Rachel J., 1997, „I Don't Know Enough”: Jewish Women's Learned Ignorance, „Women in Judaism: A Multidisciplinary Journal", t. 1, nr 1.

Sorek Susan, 2002, Mothers of Israel: Why the Rabbis Adopted a Matrilineal Principle, „Women in Judaism: A Multidisciplinary Journal", t. 3, nr 1.

Stahl Abraham, 1985, A Virtuous Woman: The Ideal Wife According to the Rabbis of the East, "Journal of Comparative Family Studies", t. 16, nr 3.

Tsoffar Ruth, 2006, The Stains of Culture: An Ethno-Reading of Karaite Jewish Women, Wayne State University Press, Detroit.

\section{WOMAN IN RELIGION - JUDAISM AND KARAISM AND THEIR INFLUENCE ON WOMAN'S ROLE IN COMMUNITY}

\section{Summary}

Social role has a strong influence on people, they want to properly fulfil their roles to gain acceptation. At the same time, living in a predictable and comprehensible world demands that others behave according to their roles. The roles we fulfil have a great impact on our identity, other people perceive us and we perceive ourselves through the roles. The thesis of this article is that religion is the scriptwriter of social roles. As an example we take communities built on religion: Judaism and Karaism. These minorities survived until today having their own tradition and identity. The phenomenon is based on dualistic approach to woman's role in the community. On one hand they have been limited to the role of a mother and a wife, on the other hand they have been burdened with responsibility for survival - in a physical and metaphorical sense - of the community. The transmission of cultural heritage and identity of Jews and Karaites depended on them. Both the theory of social roles and religious laws and traditions will be shown outlining their influence on shaping woman's role in the community back then as well as nowadays.

\section{Key words/słowa kluczowe}

gender role / rola rodzajowa; social role / rola społeczna; Karaism / karaimizm; Judaism / judaizm; culture / kultura; tradition / tradycja; religious laws / prawa religijne; identity / tożsamość; matrilineal principle / matrylineat; ideal wife / idealna żona 